\title{
Is the size of an enterprise in the construction industry an important prerequisite for its success?
}

\author{
Bořivoj Groda ${ }^{1^{*}}$ \\ ${ }^{1}$ Institute of Technology and Business in České Budějovice, School of Expertness and Valuation, \\ Okružní 517/10, 37001 České Budějovice
}

\begin{abstract}
The construction industry can currently be ranked among the most important sectors of the national economy, with a large number of companies operating within it. These undertakings differ from each other by subject of activity, place of activity, chosen strategy, the legal form of the enterprise or the size of the enterprise. This paper aims to determine what impact the size of a construction company has on its future success, with asset returns and return on equity being considered success indicators. A data sample of 3139 construction companies from between 2011 and 2015 was used for analysis. As a result, the predetermined hypotheses have been verified: a larger enterprise generates a higher ROE and a larger enterprise generates a larger ROA. It was found that the size of the company greatly affects its liquidity.
\end{abstract}

Key words: enterprise size, construction industry, ROA, ROE, liquidity

\section{Introduction}

The construction industry plays a vital role in the national economy and its long-term socioeconomic development. Its key role lies primarily in the development of housing, facilities and the infrastructure necessary for national social and economic development [1]. According to Naderpajouh, Choi and Hastak [2], the construction industry has its own specificities, primarily in the demand for capital, individuality, manual difficulty and the exceptionalism of requirements.

According to Chan and Owusu [3], the construction industry is the sector of the national economy that concerns itself with land preparation and the construction, adjustments and repair of buildings and other estates. The construction industry is thus an economic field that enables many functions such as social functions (sports, health care, housing, etc.), energy, transport, agricultural and industrial production, etc. [4].

This paper focuses on company size, which is considered to be a very important and basic trait of the enterprise. In order to determine the optimum size of a company, we can indicate the speed and range of growth that is ideal for a particular business [5]. Company size depends on many external and internal factors. Most companies are seeking to develop their activity [6]. The growth of any factor, whether revenue, profits, the number of

${ }^{*}$ Corresponding author: groda@mail.vstecb.cz 
employees or the size of facilities, is essential for almost all enterprises. Kim, Lin and Chen [7] note that for many companies competing in rapidly changing industries, expansion (production capacity, geographical presence, market share, etc.) may also be necessary for continuation.

At present, small and medium-sized enterprises are considered to be major drivers of industrial structure growth in many countries, and such sectors are very important for many developing countries seeking to revitalize their economic structure [8]. Vochozka and Mulač [9] report that the small and medium-sized enterprise sector plays a very important role in the economy, especially in job creation, as it is a factor of social stability and is conducive to the development of certain regions, cities and municipalities. This business area can therefore be labelled as the driving force in the sphere of business, growth, innovation and competitiveness. Barhatov and Belova [10] note that under the current economic conditions, the development of small and medium-sized enterprises is not possible without some financial support. National small and medium-sized enterprises have a particularly acute need for state aid. Special funds, corporations, or agencies are established [11].

Small and large enterprises differ from one another considerably. The advantage of large businesses is the possibility of career growth for employees. Large companies offer their devoted and capable employees a career to build. In addition, we can mention advantages such as benefits for employees, higher financial valuation, etc. The disadvantage of large companies lies in their decision-making thanks to a complex organizational structure and more difficult response to changes in the environment, especially in the market [12]. According to De Toni and Nassimbeni [13], small and medium-sized enterprises are often family businesses run by entrepreneurs who worked as factory employees in companies engaged in the same industry at the beginning of their careers. Therefore, they bring with them a considerable amount of technical experience that allows them to think about realizable innovative products and processes. On the other hand, these entrepreneurs suffer from a lack of managerial competencies. We can also mention lower wages as a disadvantage of small and medium-sized enterprises, therefore the total area of financing. It is also important to acknowledge that work intensity is higher in these businesses [14]. The advantage of small and medium-sized enterprises is their speed in response to a changing external environment, such as changes in demand or market [15]. Of course, as far as decision-making is concerned, small businesses are far more flexible and faster in the area of decision-making, because of the clearer and simpler organizational structure. Employee relationships are more confidential than in large businesses, which helps to build high-quality teamwork [16].

Rizos et al. [17] argue that small and medium sized enterprises are increasingly aware of the benefits of improving resource efficiency, such as saving material costs, creating competitive advantages and accessing new markets. At the same time, however, these businesses are aware of their problems stemming of lack of finance and managerial skills. Grando and Belvedere [18], however, argue that small and medium-sized enterprises perform worse than large enterprises, due to the lack of human and financial resources that prevent small and medium-sized enterprises from adopting new technological solutions and innovative management practices needed to improve overall performance.

Therefore, the aim of the paper is to determine whether the size of an enterprise indicates its future success. We can verify several hypotheses as to which variable will be considered an indicator of success. In this article, we look at the enterprise through the eyes of its owners. We will consider return on equity and return on assets as indicators of success. 
The hypotheses are thus:

1. A larger enterprise generates a higher $\mathrm{ROE}^{1}$.

2. A larger enterprise generates a higher $\mathrm{ROA}^{2}$.

\section{Data and methods}

Data from a sample of construction enterprises from the Albertina database will be used in the analysis. The sample of businesses will consist of micro, small, medium and large enterprises. The size of the business will be determined by the number of employees in the enterprise. The total set consists of 3139 records from the period of 2011 to 2015. The representation of enterprises in the data file for individual years by size is evident in Table 1.

Table 1. Division of enterprises in sample surveyed.

\begin{tabular}{|c|c|c|c|c|c|c|}
\hline \multirow[b]{2}{*}{ Quantity } & \multicolumn{5}{|c|}{ Year } & \multirow{2}{*}{ Total sum } \\
\hline & 2011 & 2012 & 2013 & 2014 & 2015 & \\
\hline 0 & 51 & 60 & 64 & 49 & 52 & 276 \\
\hline 3 & 104 & 96 & 87 & 102 & 94 & 483 \\
\hline 7 & 26 & 27 & 19 & 23 & 24 & 119 \\
\hline 15 & 110 & 114 & 118 & 119 & 114 & 575 \\
\hline 23 & 23 & 37 & 34 & 32 & 36 & 162 \\
\hline 38 & 65 & 47 & 45 & 47 & 49 & 253 \\
\hline 75 & 133 & 130 & 139 & 132 & 123 & 657 \\
\hline 150 & 60 & 63 & 50 & 56 & 65 & 294 \\
\hline 225 & 6 & 7 & 11 & 12 & 12 & 48 \\
\hline 375 & 37 & 35 & 34 & 39 & 36 & 181 \\
\hline 750 & 13 & 13 & 10 & 6 & 7 & 49 \\
\hline 1250 & 2 & 2 & 4 & 3 & 3 & 14 \\
\hline 1750 & 4 & 4 & 2 & 2 & 1 & 13 \\
\hline 2250 & 1 & 1 & 1 & 2 & 1 & 6 \\
\hline 2750 & & & & & 1 & 1 \\
\hline 3500 & 1 & 1 & 2 & 2 & & 6 \\
\hline 4500 & 1 & 1 & & & & 2 \\
\hline Total sum & 637 & 638 & 620 & 626 & 618 & 3139 \\
\hline
\end{tabular}

The division corresponds to the actual representation of enterprises in the different size segments of the construction industry in the years 2011 to 2015 . This is a selection equal to one twentieth of all enterprises operating in the construction sector in the observed period. Figure 1 summarizes the number of enterprises in the sample throughout the observed period.

${ }^{1} \mathrm{ROE}=$ Return on Equity

${ }^{2} \mathrm{ROA}=$ Return on Assets 


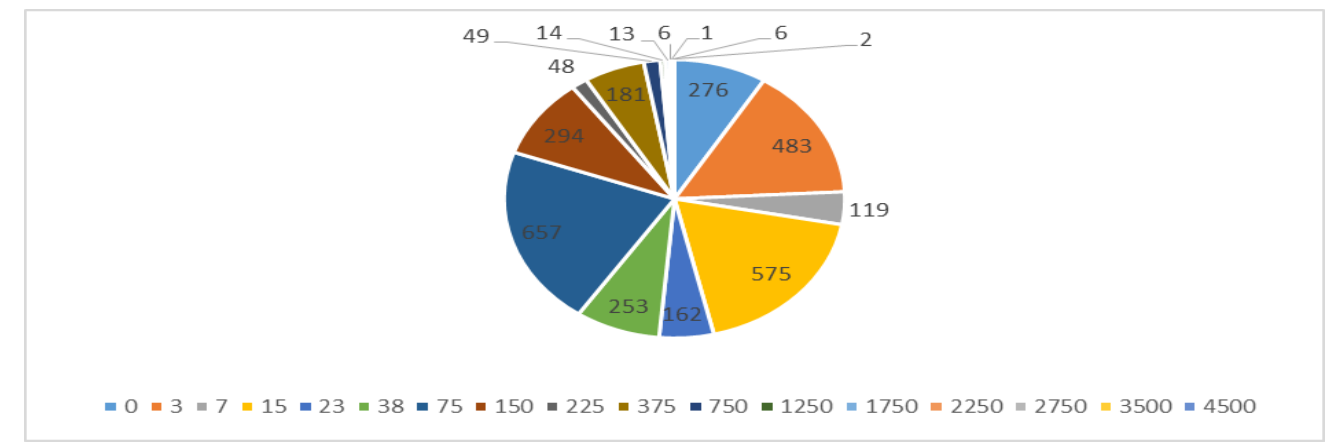

Fig. 1. Total division of enterprises by size.

Using graphical methods, we will investigate the ROE and ROA dependence on enterprise size, as predicted by the hypotheses. It can be assumed that the value of both indicators will increase with growth in enterprise size.

In addition, we will examine other indicators in which the size of the company can be reflected - indicators of liquidity or possibly of the company's indebtedness.

\section{Results}

Figure 2 shows the pattern of return on equity as dependent on the size of the enterprise

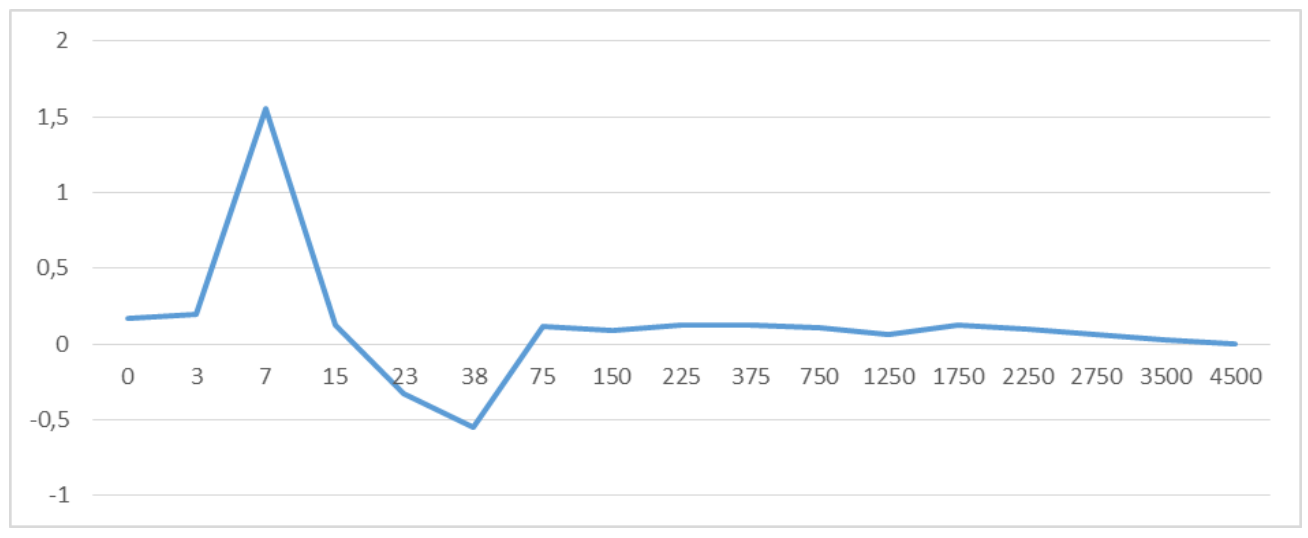

Fig. 2. Average ROE of the sample of enterprises surveyed.

The figure shows a large deviation in enterprises with seven employees, with a ROE of over 1.5. The ROE then drops to negative values. It reaches the lowest value for enterprises with 38 employees (less than -0.5 ), then subsequently grows and maintains positive values for the largest enterprises. Figure 3 shows why fluctuations have occurred on both sides. 


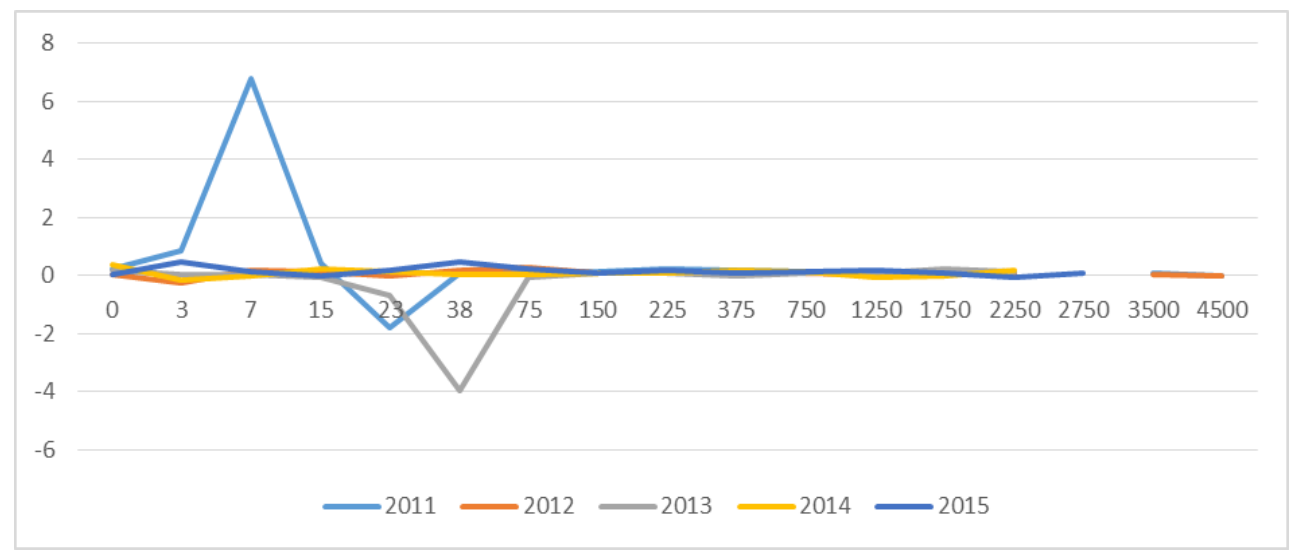

Fig. 3. The average ROE of enterprises in individual years.

The deviation in enterprises with seven employees was caused by results from the year 2011, when the ROE of these enterprises reached an average of approximately 7 . In the case of enterprises with 38 employees, the fluctuation was caused by an average ROE of almost -4 in the year 2013. Under other conditions, the value of ROE stayed slightly above zero throughout the observed period. Thus, if we disregard the extreme values, we can state that hypothesis number one has not been fulfilled. The size of an enterprise does not affect the ROE value.

The circumstances are significantly more complex in the case of ROA. The entire situation for the set of enterprises surveyed is illustrated in picture 4 .

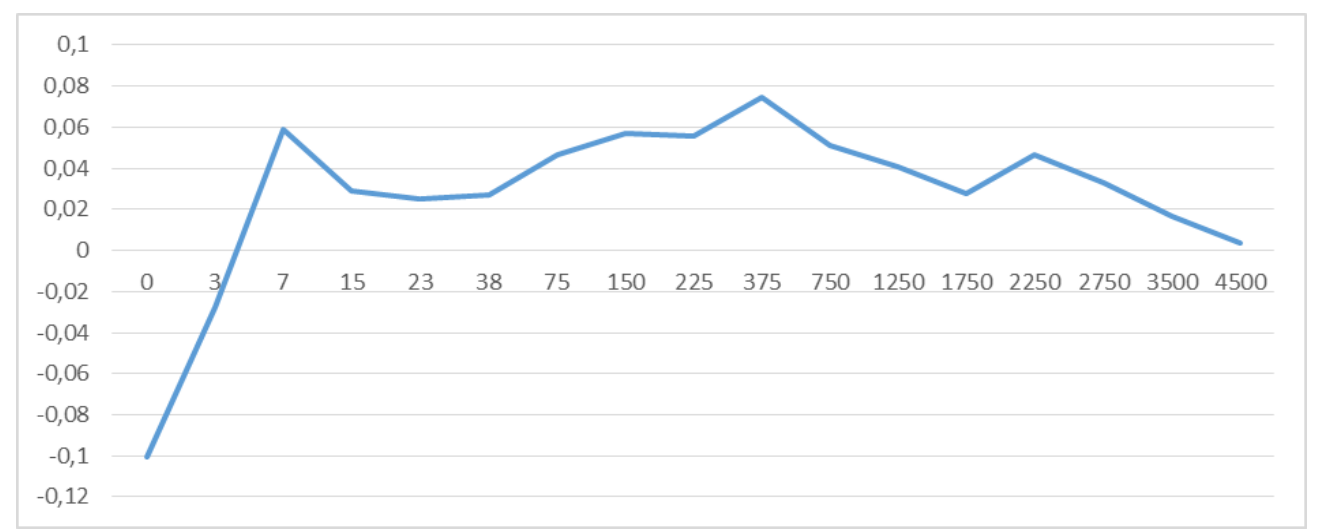

Fig. 4. Average ROA for the set of enterprises surveyed.

The lowest value of ROA is evident in companies with no employees. Specifically, it reaches 0.1, then starts rising. The first peak is reached by businesses with seven employees. Further in its course, it falls to reach its peak for businesses with 375 employees. Then it begins declining, while, however, maintaining positive ROA values. Overall, it ranges from - 0.1 to just below 0.8 .

The progress over individual years is the subject of figure 5. The interval increases to values from - 0.3 to 1.3 . Fluctuations, however, are basically minimal, just as with the average ROA (Figure 4). It should be noted that the development of ROA appears to be more stable and predictable in larger companies for individual years of the surveyed period. 
Deviations can only be found in small and medium-sized enterprises (up to 38 employees), they keep decreasing further down the interval with results appearing quite similar.

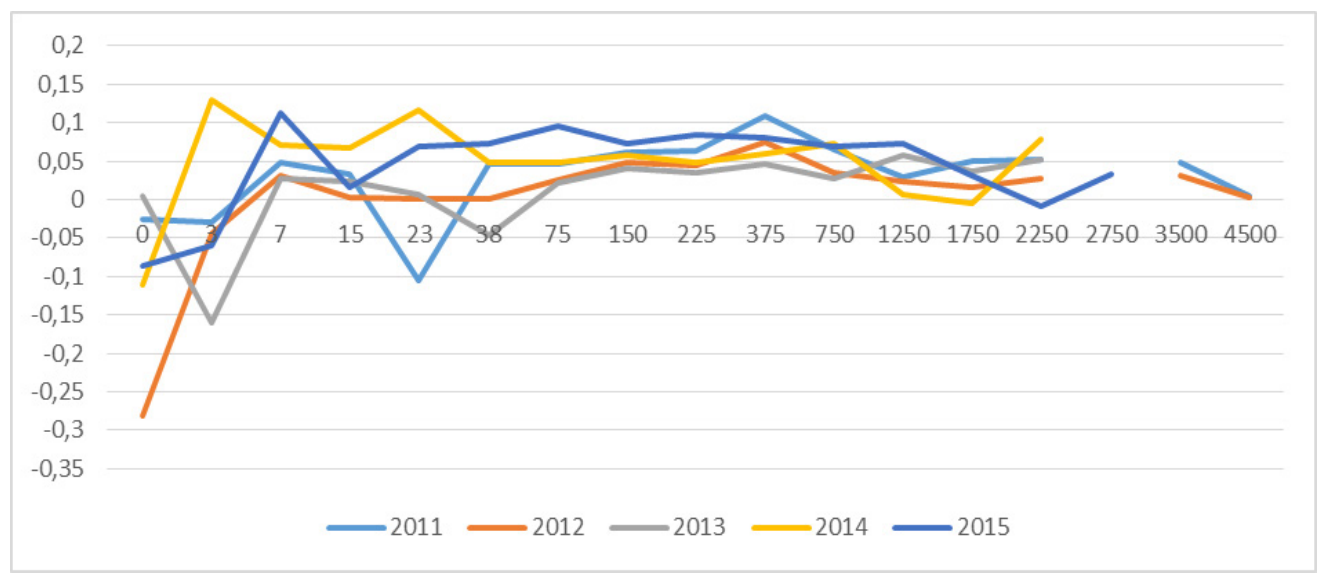

Fig. 5. Average ROA of enterprises during individual years.

Even these results are insufficient to prove that the size of an enterprise could have a positive effect on the ROA.

Of course, one can think that the relationship between enterprise size and some other indicators would be more prominent. As already indicated in the methods of the article, we will focus our attention on the company's indebtedness (i.e. the ability to utilize the resources and potential of the company). The company's indebtedness with respect to the size of the company can be seen in figure 6 .

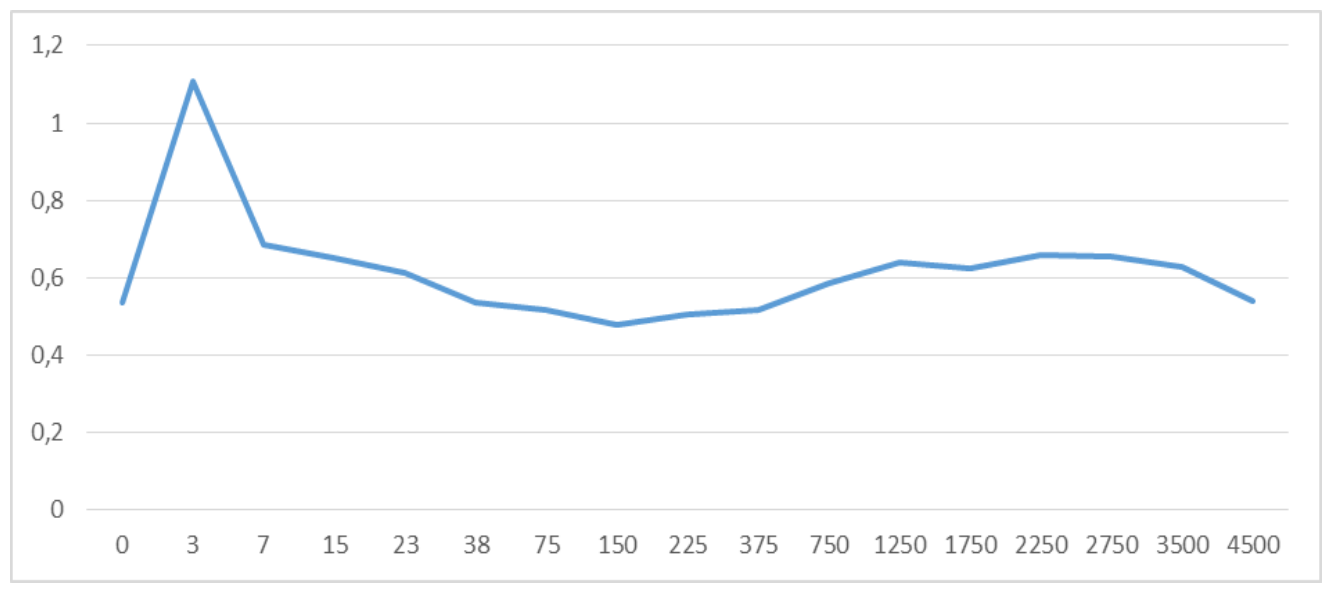

Fig. 6. Average indebtedness of enterprises in respect to their size.

The figure shows a fluctuation in enterprises employing 3 workers, where the average indebtedness is more than 1.1. This means that an average enterprise of this size is overindebted, and if so in the long-term, it should end its activity. Otherwise, it can be stated that the average indebtedness for all sizes of construction enterprises is approximately comparable, ranging from 0.5 to 0.65 . Again, we can say that the size of the enterprise is not relevant. 
If we consider indebtedness in the context of the ROE value, the progress of indebtedness only confirms the progress of the ROE. It is obvious that the companies are not concerned with the effects of financial leverage, or more precisely, its positive effects cannot be demonstrated. In general, it can be assumed that large businesses would be more indebted, generating higher ROEs than other businesses. However, this cannot be confirmed.

Let us examine, however, the relationship between the size of the company and its liquidity. Figure 7 provides the cash flow of an enterprise in accordance to its size.

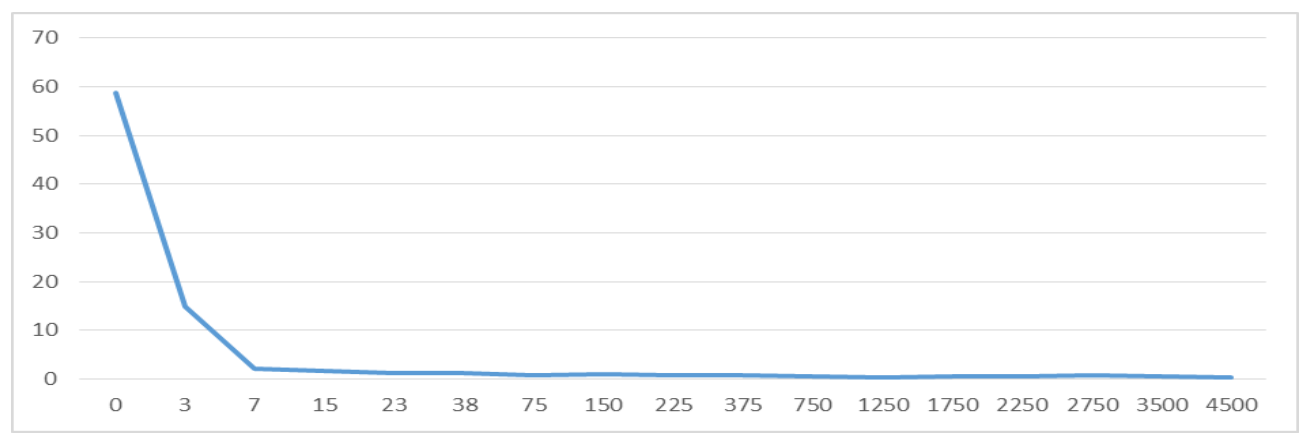

Fig. 7. Average financial liquidity of enterprises by size.

It is clear from the graph that small businesses with a total of seven employees deal with financial liquidity very inefficiently. They hold large stocks of funds. In general, we can say that they fear risk. size.

Figure 8 represents the flow of instant and total liquidity of a business in respect to its

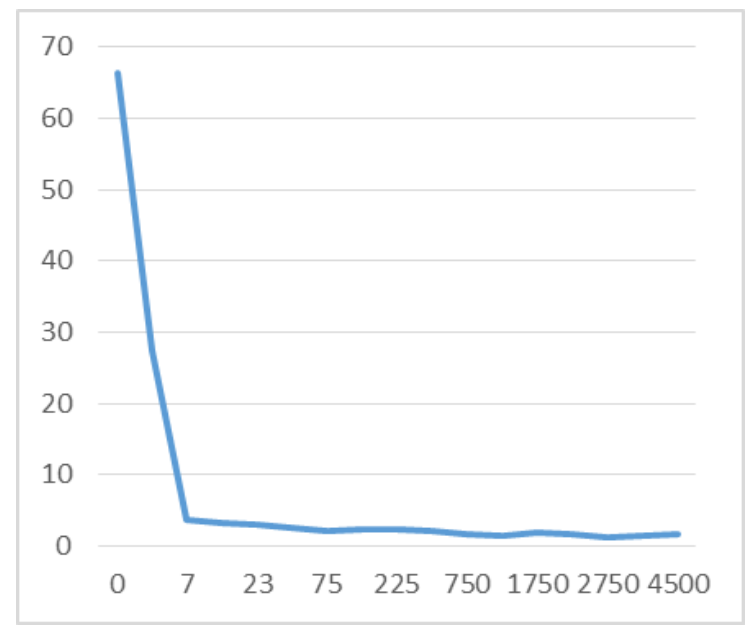

Fig. 8. Average liquidity.

The progress of instant and total liquidity is identical to the progress of financial liquidity. Small businesses are concerned about possible insolvency. Therefore, they manage money very inefficiently. By contrast, large businesses hold a minimum money stock and are therefore more efficient. However, not even this aspect of management has been reflected in the ROE and ROA results. 


\section{Conclusion}

The aim of the article was to determine whether the size of an enterprise indicates its future success. Two hypotheses were set to support the goal of the paper:

1. A larger enterprise generates a higher ROE.

2. A larger enterprise generates a higher ROA.

The hypothesis number 1, a larger enterprise generates a higher ROE, has been disproven. We can state that the size of a company in the construction industry did not have an effect on the ROE.

The hypothesis number 2, a larger enterprise generates a higher ROA, has also been disproven. The size of a company in the construction industry did not affect the ROA.

The aim of the article has been met. In the context of result discussion, it was found that the size of the company had a major impact on the development of the company's liquidity. Small enterprises, or more specifically micro-enterprises with up to 7 employees, have an aversion to risk, keep a large stock of money and thus behave inefficiently. By contrast, large corporations manage their liquidity very carefully and therefore behave responsibly. However, not even very precise liquidity management has been reflected in higher ROE and ROA values.

\section{References}

1. Z. Rowland, J. Vrbka, Optimization of a company's property structure aiming at maximization of its profit using neural networks with the example of a set of construction companies. Mathematical Modelling in Economics [Математичне моделювання в економіці], 7(3-4) (2016)

2. N. Naderpajouh, J. Choi, M. Hastak, Exploratory Framework for Application of Analytics in the Construction Industry. Journal of Management in Engineering, 32(2), (2016)

3. P. C. Chan, E. K. Owusu, Corruption Forms in the Construction Industry: Literature Review. Journal of Construction Engineering and Management, 143(8), (2017)

4. P. Šuleř, Optimizing the capital structure of the company to maximize its profits by using neural networks on the example of building companies. Mathematical Modelling in Economics [Математичне моделювання в економіці], 7(3-4), (2016)

5. P. Wei, L. Xu, B. Zeng, Corporate hedging, firm focus and firm size: the case of REITs. Managerial Finance, 43(3), (2017)

6. D. C. Joaquin, a N. Khanna, Investment timing decisions under threat of potential competition: Why firm size matters. The Quarterly Review of Economics and Finance, 41(1), (2001)

7. D. Kim, S.-Ch. Lin, T.-C. Chen, Financial structure, firm size and industry growth. International Review of Economics, 41, (2016)

8. H. Esmailpour, M .R.Tavallai, Innovative marketing and competitive advantage of small and medium-sized businesses according to the entrepreneurial orientation and Features. International Journal of Advanced Biotechnology and Research, 7(3), 1130$1143(2016)$ 
9. M. Vochozka, M, P. Mulač, Financial management. In Business economics [Finanční řízení. In. Podniková ekonomika]. $1^{\text {st }}$ ed. Prague: Grada (2012)

10. V. Barhatov, I. Belova, Infrastructure of state support of small and medium-sized business in Russia. Proceedings of the $16^{\text {th }}$ International Scientific Conference on Economic and Social Development - The Legal Challenges of Modern World, 508-517 (2016)

11. M. Vochozka, M. Psárska, Factors supporting growth of added value, performance and competitiveness of SMEs and selected EU countries. Innovation Management Entrepreneurship and Corporate Sustainability, 756-767 (2016)

12. G. S. Dangayach, S. G. Deshmukh, Manufacturing strategy. International Journal of Operations, 21(7), (2001)

13. A. De Toni, G. Nassimbeni, Small and medium district enterprises and the new product development challenge. International Journal of Operations, 23(6), (2003)

14. A. Kasych, M. Vochozka, Theoretical and methodical principles of managing enterprise sustainable development. Marketing and Management of Innovations, (2), (2017)

15. M. Vochozka, Z. Rowland, The evaluation and prediction of the viability of construction enterprises. Littera Scripta, 8(1), (2015)

16. M. Starbek, J. Grum, Concurrent engineering in small companies. International Journal of Machine Tools and Manufacture, 42(3), (2002)

17. V. Rizos, A. Behrens, W. V. Gaast, et al, Implementation of Circular Economy Business Models by Small and Medium-Sized Enterprises (SMEs): Barriers and Enablers. Sustainability, 8(11), 1212-1230 (2016)

18. A. Grando, A, V. Belvedere, District's manufacturing performances: A comparison among large, small to medium sized and district enterprises. International Journal of Production Economics, 104(1), (2006) 
